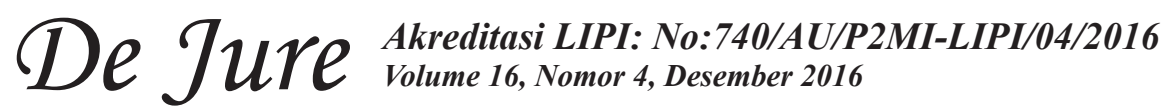

Jurnal Penelitian Hukum De Jure adalah majalah hukum triwulan (Maret, Juni, September dan Desember) diterbitkan oleh Badan Penelitian dan Pengembangan Hukum dan HAM Kementerian Hukum dan HAM RI bekerjasama dengan IKATAN PENELITI HUKUM INDONESIA (IPHI) Pengesahan Badan Hukum Perkumpulan Keputusan Menteri Hukum dan Hak Asasi Manusia Nomor : AHU-13.AHA.01.07 Tahun 2013, Tanggal 28 Januari 2013, bertujuan sebagai wadah dan media komunikasi, serta sarana untuk mempublikasikan aneka permasalahan hukum yang aktual dan terkini bagi para peneliti hukum Indonesia khususnya dan kalangan masyarakat pemerhati hukum pada umumnya.

Penanggung Jawab

Y. Ambeg Paramarta, S.H.,M.Si

(Kepala Badan Penelitian dan Pengembangan Hukum dan Hak Asasi Manusia)

\section{Pemimpin Umum}

Marulak Pardede, S.H.,M.H.,APU

(Ketua Ikatan Peneliti Hukum Indonesia)

\section{Wakil Pemimpin Umum}

T. Daniel L. Tobing, S.H

(Kepala Pusat Pengembangan Data dan Informasi Peneliti Hukum dan Hak Asasi Manusia)

DR. Agus Anwar, S.H.,M.H

(Kepala Pusat Penelitian dan Pengembangan Hukum)

Pemimpin Redaksi

Akhyar Ari Gayo, S.H.,M.H.,APU (Hukum Islam, BALITBANGKUMHAM)

\section{Anggota DewanRedaksi}

DR. Ahmad Ubbe, S.H.,M.H., APU (Hukum Adat, BALITBANGKUMHAM)

Mosgan Situmorang, S.H.,M.H (Hukum Perdata, BALITBANGKUMHAM)

Syprianus Aristieus, S.H.,M.H (Hukum Perusahaan, BALITBANGKUMHAM)

Nevey Varida Ariani, S.H.,M.H (Hukum Pidana, BALITBANGKUMHAM)

Eko Noer Kristiyanto, S.H (Hukum Perdata, BALITBANGKUMHAM)

Muhaimin, S.H (Hukum Islam, BALITBANGKUMHAM)

\section{Redaksi Pelaksana}

Yatun, S.Sos

Sekretaris

M. Virsyah Jayadilaga, S.Si.,M.P

Asmadi

\section{Tata Usaha}

Dra. Evi Djuniarti, M.H

Galuh Hadiningrum, S.H

Suwartono 


\section{TUTe $\begin{aligned} & \text { Akreditasi LIPI: No:740/AU/P2MI-LIPI/04/2016 } \\ & \text { Volume 16, Nomor 4, Desember } 2016\end{aligned}$}

Teknologi Informasi dan Desain Layout

Risma Sari, S.Kom., M.Si (Teknologi Informasi)

Machyudhie, S.T (Teknologi Infornasi)

Saefullah, S.ST.,M.Si (Teknplogi Informasi)

Agus Priyatna, S.Kom (Desain Layout)

Teddy Suryotejo

\section{Mitra Bestari}

Prof. DR. Rianto Adi, M.A (Sosilogi Hukum, UNIKA ATMAJAYA JAKARTA)

Prof. DR. Jeane Neltje Saly, S.H.,M.H (Hukum Humaniter, UNIV. 17 Agustus 1945 Jakarta)

Prof. DR. Hibnu Nugroho, S.H (Hukum Fidana, FH. UNSOED)

DR. Farhana, S.H.,M.H (Hukum Pidana, Fak. Hukum Universitas Islam Jakarta)

DR. Ridwan Nurdin, M.A (Hukum Syariah, Fakultas Syariah Univ. Arraniri Banda Aceh)

DR. Hadi Supratikta (Administrasi Pemerintahan, Balitbang Kemendagri)

\section{Alamat Redaksi:}

Gedung Badan Penelitian dan Pengembangan Hukum dan Hak Asasi Manusia

Kementerian Hukum dan Hak Asasi Manusia Republik Indonesia

Jl. HR. Rasuna Said Kav.4-5, Kuningan, Jakarta Selatan

Telepon, (021)2525015, Faksimili (021) 2526438

Email :

jurnaldejure@yahoo.com

balitbangkumham@gmail.com

ejournaldejure@gmail.com

\section{Percetakan}

PT Pohon Cahaya

Jalan Gedung Baru 18 Jakarta Barat 11440

Telpon (021) 5600111, Faksimili (021) 5670340

Redaksi menerima naskah karya asli yang aktual dalam bidang hukum berupa hasil penelitian dari berbagai kalangan, seperti: peneliti hukum, praktisi dan teoritisi, serta berbagai kalangan lainnya. Tulisan-tulisan yang dimuat merupakan pendapat pribadi penulisnya, bukan pendapat redaksi.

Redaksi berhak menolak, menyingkat naskah tulisan sepanjang tidak mengubah isinya. Naskah tulisan dapat dikirim ke alamat redaksi, maksimum 30 halaman A4, diketik spasi dua rangkap dikirim melalui Email: jurnaldejure@yahoo.com atau melalui aplikasi Open Journal System (OJS) pada URL/website: ejournalbalitbangham.go.id 


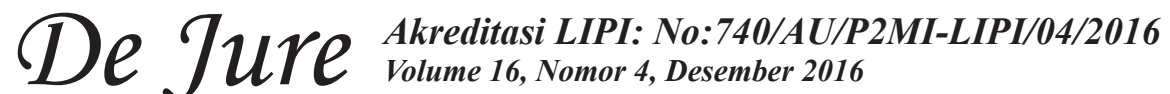

\section{DAFTAR ISI}

Halaman

\section{DAFTAR ISI}

ADVERTORIAL

Penyelesaian Konflik Sosial (Studi Kasus Tawuran Warga Berlan dengan Palmeriam)

(Social Conflict Completion According To The Law Number

7/2012(Case Study of Brawl Between Berlan And Palmeriam Residents))

$493-504$

Yuliyanto

DAFTAR RIWAYAT HIDUP

$.505-506$

PEDOMAN PENULISAN 


\section{De TuPe $\begin{aligned} & \text { Akreditasi LIPI: No:740/AU/P2MI-LIPI/04/2016 } \\ & \text { Volume 16, Nomor 4, Desember } 2016\end{aligned}$}

Puji syukur kehadirat Allah SWT, Jurnal Penelitian Hukum De Jure yang diterbitkan Badan Penelitian dan Pengembangan Hukum dan HAM Kementerian Hukum dan Hak Asasi Manusia bekerjasama dengan Ikatan Peneliti Hukum Indonesia dapat menerbitkan Volume 16 Nomor 4, Desember 2016.

Para pembaca Jurnal Penelitian Hukum De Jure yang tercinta, sebagaimana diketahui bahwa pada tanggal 10 Desember setiap tahunnya diperingati sebagai Hari Hak Asasi Manusia sedunia. Tanggal ini dipilih untuk menghormat Majelis Umum PBB yang mengadopsi dan memproklamirkan Deklarasi Universal Hak Asasi Manusia, sebuah pernyataan global tentang hak asasi manusia pada 10 Desember 1948.

Apabila menilik Hukum dan HAM, merupakan konsepsi kemanusiaan dan relasi sosial yang dilahirkan dari sejarah peradaban manusia di seluruh penjuru dunia. Hukum dan HAM juga dapat dimaknai sebagai hasil perjuangan manusia untuk mempertahankan dan mencapai harkat kemanusiaannya. Agar HAM dapat ditegakkan dalam berbagai kehidupan harus ada instrumen yang mengaturnya. Instrumen tersebut berisi aturanaturan bagaimana HAM itu ditegakkan dan mengikat seluruh warganegara. Sebagai negara yang menjunjung tinggi HAM Indonesia telah memiliki setidak-tidaknya empat instrumen HAM, yakni UUD 1945, TAP MPR Nomor XVII/MPR/1998, UU Nomor 39 Tahun 1999 tentang Hak Asasi Manusia.

Dari beberapa intrumen yang ada tersebut berharap perlindungan dan penegakan HAM kedepanya dapat meningkat, karena masih banyak kekurangan-kekurangan yang harus diperbaiki oleh pemerintah. Seperti lebih difungsikan secara maksimal lembaga-lembaga yang memiliki tugas khusus menegakan HAM.

Dalam rangka memperingati Hari Hak Asasi Manusia Sedunia tersebut, Dewan Redaksi mengangkat tuisan-tulisan dari para peneliti di lingkungan Kementerian Hukum dan HAM yang bersinggungan dengan penegakan Hukum dan HAM di Indonesia.

Akhirnya kami menyampaikan ucapan terima kasih kepada Kepala Badan Penelitian dan Pengembangan Hukum dan HAM Kementerian Hukum dan HAM RI dan Ketua Ikatan Peneliti Hukum Indonesia dalam penerbitan buku ini. Dan juga kami ucapkan terima kasih kepada Prof. DR. Rianto Adi, M.A., Prof. DR. Jeane Neltje Saly, S.H.,M.H., Prof. DR. Hibnu Nugroho, S.H., DR. Farhana, S.H., M.H., DR. Ridwan Nurdin, M.A.,dan DR. Hadi Supratikta, Selaku Mitra Bestari yang telah bersedia membantu memeriksa dan mengoreksi tulisan dari para penulils.

Jakarta, Desember 2016 


\title{
PENYELESAIAN KONFLIK SOSIAL (Studi Kasus Tawuran Warga Berlan dengan Palmeriam) (Social Conflict Completion According To The Law Number 7/2012 (Case Study of Brawl Between Berlan And Palmeriam Residents))
}

\author{
Yuliyanto \\ Peneliti pada Pusat Penelitian dan Pengembangan Hukum, Badan Penelitian \\ dan Pengembangan Hukum dan Hak Asasi Manusia \\ Kementerian Hukum dan Hak Asasi Manusia Republik Indonesia \\ Jalan HR Rasuna Said Kavling 4 -5, Jakarta Selatan 12920 \\ Telepon (021)2525015 Faksimili (021)2526438 \\ HP: 08121065634 - Email: yuliyanto_oke@yahoo.com \\ Tulisan Diterima: 2-09-2016; Direvisi: 5-12-2016; \\ Disetujui Diterbitkan: 23-12-2016
}

\begin{abstract}
This research identifies two issues: firstly: conflict between Berlan and Palmerian residents has been occurred for long times until now; secondly: need a solution in finishing the conflict and find sources of problem. From identification above, it will elaborate into items that is (1) what causative factors of conflict; (2) what the impacts of that conflict; (3) what efforts of government to finish the conflict according to mandate of the Act Number 7 Year 2012. The method in collecting data is interview with relevant informant to research issues. This research is role of government to satisfy rights of society security. It concludes that find some factors cause its conflict between Berlan and Palmeriam residents, but misunderstanding and juvenile delinquency are dominant factors lead that conflict.
\end{abstract}

Keywords: completion, social conflict

\begin{abstract}
ABSTRAK
Penelitian ini mengidentifikasi dua permasalahan: Pertama,konflik antara warga Berlan dan Palmeriam yang sudah berlangsung sejak lama dan masih terjadi sampai sekarang; Kedua, bagaimana menyelesaikan konflik antara warga Berlan dengan Palmeriam dan apaakar permasalahannya. Ketiga, apa dampak dari terjadinya konflik antara warga Berlan dengan Palmeriam; Keempat,upaya penyelesaian yang telah dilakukan oleh Pemerintah dalam menyelesaikan tawuran antar warga Berlan dengan Palmeriam sesuai dengan amanat UndangUndang Nomor 7 Tahun 2012. Metode yang digunakan dalam pengumpulan data, peneliti menggunakan teknik wawancara kepada beberapa informan, yakni: tokoh masyarakat (Ketua RW dan Ketua FKDM), pemerintah daerah (Lurah Kebon Manggis dan Lurah Palmeriam, Kepala Seksi Pemerintahan dan Kamtib Kelurahan Kebon Manggis dan Kelurahan Palmeriam, dan Kepala Sub Bidang Kewaspadaan Kantor Kesbangpol Jakarta Timur, dan Kepala Kepolisian Sektor Matraman. Penelitian ini merupakan wujud dari peran serta Pemerintah dalam memenuhi hak atas rasa aman bagi masyarakat. Hasil penelitian menyimpulkan bahwa, meskipun ada beberapa faktor yang menyebakan konflik antara warga Berlan dengan Palmeriam, namun kesalahpahaman dan kenakalan remaja merupakan faktor yang dominan penyebab konflik tersebut.
\end{abstract}

Kata kunci: Penyelesaian, Konflik Sosial, 


\section{PENDAHULUAN}

Pada tahun 2012 Pemerintah mengeluarkan Undang-Undang Nomor 7 Tahun 2012 tentang Penanganan Konflik Sosial. Dalam rangka menangani konflik, pada tahun 2012 pemerintah mengeluarkan Undang-Undang Nomor 7 Tahun 2012 tentang Penanganan Konflik Sosial. Landasan filosofis keberadaan Undang-Undang Nomor 7 Tahun 2012 adalah upaya penciptaan suasana yang aman, tenteram, tertib, damai, dan sejahtera baik lahir maupun batin sebagai wujud hak setiap orang atas perlindungan agama, diri pribadi, keluarga, kehormatan, martabat, dan harta benda. Landasan sosiologisnya adalah banyaknya timbulnya perseteruan dan /atau benturan antar kelompok masyarakat dapat menimbulkan konflik sosial yang mengakibatkan terganggunya stabilitas nasional dan terhambatnya pembangunan nasional. Landasan yuridisnya yaitu, ketentuan peraturan perundang-undangan yang berkaitan dengan penanganan konflik sosial masih bersifat parsial dan belum komprehensif sesuai dengan dinamika dan kebutuhan hukum masyarakat.

Pada Pasal 5 butir a Undang-Undang Nomor 7 Tahun 2012 tentang Penanganan Konflik Sosial, disebutkan bahwa konflik dapat bersumber dari: permasalahan yang berkaitan dengan politik, ekonomi, dan sosial budaya. Demikian pula seperti kasus tawuran yang terjadi akhir-akhir ini di Jakarta, sebagaimana yang terjadi di daerah Berlan dan Palmeriam, jika dirunut dari awal (dahulu) salah satu penyebab tawuran tersebut adalah faktor politik. Maraknya kasus tawuran antar warga perlu menjadi perhatian pemerintah dan tokoh masyarakat. Tawuran sosial bukan hanya merugikan dua pihak yang bertikai tetapi juga merugikan masyarakat secara umum. Selain faktor politik, beberapa kasus tawuran di Provinsi DKI Jakarta diduga disebabkan oleh banyaknya problem sosial kemasyarakatan yang perlu penyelesaian secara komprehensif, diantaranya banyaknya pengangguran, kemiskinan, kesenjangan sosial, kurangnya pendidikan, kondisi rumah tidak layak huni, dan lingkungan yang kumuh.

Menurut Kapolda Metro Jaya Inspektur Jenderal Tito Karnavian (yang menjabat pada saat penelitian ini dilakukan) menjelaskan bahwa: tawuran merupakan masalah yang kompleks, jadi permasalahan sosial banyak muncul disitu. Makin banyak orang makin banyak interaksi sosial, makin banyak juga potensi konflik karena perbedaan kepentingan. Diketahui, selama Operasi Ketupat Jaya 2015, telah terjadi enam aksi tawuran warga di Jakarta. Jumlah ini meningkat 100 persen dibandingkan tahun lalu. Sementara pada 16 hari sebelum Operasi Ketupat Jaya 2015 terdapat 20 aksi tawuran (Merdeka.com/jakarta/kapoldametro-bakal-bertemu-ahok-bahas-maraknyatawuran-warga.html).

Wakil Gubernur DKI Jakarta, Djarot Saiful Hidayat menegaskan bahwa Jakarta Timur merupakan wilayah paling banyak terjadi kasus tawuran. Sejak Januari hingga Juli 2015 tercatat terjadi 23 aksi tawuran antar kampung di wilayah Jakarta Timur. Menyikapi masalah tersebut, Wakil Gubernur DKI Jakarta meminta seluruh jajaran meliputi lurah, camat, dan satuan polisi pamong praja untuk lebih aktif melakukan tindakan preventif pada daerah yang menjadi pusat tawuran. Salah satu upaya preventif untuk mencegah tawuran antar warga adalah berupa safari ramadhan mengunjungi daerah-daerah yang rawan tawuran, telah ada kesepakatan damai namun ternyata kasusnya terulang lagi (Poskotanews.com/ 2015/07/28/wagub-jakartatimur-terbanyak-kasus-tawuran).

Tawuran antar warga Berlan dengan warga Palmeriam telah berlangsung berkali-kali sejak 1970-an, namun sampai sekarang masih saja terjadi tawuran. Kawasan Matraman, oleh sebagian orang yang sudah lama bermukim dulu dikenal sebagai daerah segitiga merah. Tawuran antar warga di kawasan ini menurut Cholid warga Palmeriam awalnya hanya melibatkan orangorang yang berada di asrama Ambon (Hotel Mega Matra) dengan warga Berlan (Komplek Kesatrian TNI AD). Dalam perkembangannya, setelah asrama tergusur oleh Hotel Mega Matra, konflik pertikaianpun menjalar ke Palmeriam dan sekitarnya (Roeshman.blogspot.com/2008/06/ perseteruan-bebuyutan-di-kawasan.html? $\mathrm{m}=1$ diakses 10 Agustus 2015 pukul 13.34 Wib). Dulu perseteruan antar warga di kawasan Matraman Jakarta Timur lebih banyak dipicu karena masalah ideologi, misalnya seperti yang terjadi antar simpatisan Golkar dan PPP. Para Pemuda Berlan yang sebagian besar "anak tangsi" dan banyak menjadi anggota Forum Komunikasi Putra-Putri Purnawirawan ABRI (FKPPI) menjadi pendukung Golkar. Sedangkan warga Palmeriam dan Tegalan di seberangnya lebih banyak menjagokan PPP. 


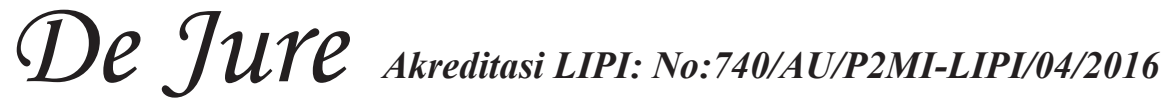

Ini terlihat pada saat-saat kampanye Pemilu. Bila kampanye lewat di daerah Palmeriam dan Tegalan, Golkar sering mendapat ejekan. Hal sama juga terjadi saat kampanye PPP melewati Berlan. Buntutnya, lalu terjadi beberapa kali bentrokan (Shahab, 2001: 67).

Aksi tawuran warga di kawasan Berlan, Jakarta Timur terakhir terjadi pada tanggal 17 Juli 2015. Menurut informasi, tawuran ini terjadi karena saling ledek saat takbir keliling. Salah satu kelompok mengejek kelompok lain yang konvoi. Tindakan meledek berujung pada tawuran yang melibatkan ratusan warga (Detik.com/news/ berita/2970679/tawuran-warga-pecah-di-berlanwarga-bawa-pedang-dan-lempar-batu).

Penelitian mengenai Penyelesaian Konflik Warga Berlan dengan Palmeriam ini, sebelumnya juga pernah dilakukan oleh Soni Akhmad Nulhaqim dengan judul Manajemen Kolaborasi Resolusi Konflik dalam Perkelahian antar Warga di Daerah Perkotaan (2005), namun sampai sekarang tawuran tersebut masih terjadi. Jika aksi tawuran ini dibiarkan, akan menimbulkan kerugian materiil dan non materiil bagi masyarakat, bahkan dikhawatirkan akan menimbulkan korban jiwa. Penelitian yang kami lakukan ingin mengetahui kondisi terakhir perkembangan (progress) mengenai tawuran antara warga Berlan dengan Palmeriam, dan ingin mengetahui mengapa tawuran tersebut masih terus terjadi. Apakah mekanisme penyelesaian konflik telah ada dan dapat diterapkan di lapangan, atau bahkan perlu dilakukan perbaikan mekanisme penyelesaian konflik.

Dari latar belakang tersebut diperoleh permasalahan sebagai berikut:

(1) Apa yang menjadi faktor penyebab konflik antara warga Berlan dengan Palmeriam?; (2) apa dampak dari terjadinya konflik antara warga Berlan dengan Palmeriam?; dan (3) upaya penyelesaian yang telah dilakukan oleh Pemerintah dalam menyelesaikan tawuran antar warga Berlan dengan Palmeriam, sesuai dengan amanat UndangUndang Nomor 7 Tahun 2012?

Hasil penelitian ini diharapkan dapat dijadikan sebuah rekomendasi yang dituangkan dalam Risalah kebijakan (policy brief) mengenai upaya penyelesaian konflik antara warga Berlan dan Palmeriam yang ditujukan kepada Pemerintah Provinsi DKI Jakarta $c q$ Pemerintah Kota Administrasi Jakarta Timur. Sehingga dengan dimanfaatkannya hasil penelitian ini oleh lembaga/instansi terkait maka dapat tercapai salah satu Indikator Kinerja Utama Badan Penelitian dan Pengembangan Hukum dan HAM yaitu dimanfaatkannya hasil penelitian dan pengembangan dalam perumusan kebijakan.

Ruang lingkup penelitian ini adalah konflik antara warga Berlan dengan Palmeriam Jakarta Timur. Konflik yang dimaksud dalam penelitian ini adalah tawuran antara warga Berlan dengan Palmeriam yang berujung pada kekerasan yang terjadi dalam kurun waktu 2010-2015. Pasal 1 Undang-Undang Nomor 7 Tahun 2012 tentang Penanganan Konflik Sosial, menjelaskan bahwa konflik adalah perseteruan dan/atau benturan fisik dengan kekerasan antara dua kelompok masyarakat atau lebih yang berlangsung dalam waktu tertentu dan berdampak luas yang mengakibatkan ketidakamanan dan disintegrasi sosial sehingga mengganggu stabilitas nasional dan menghambat pembangunan nasional. Jika dikaitkan dengan konflik antara warga Berlan dengan Palmeriam, konflik tersebut juga mengakibatkan ketidaknyamanan warga sekitar, ataupun warga yang melintas pada saat terjadi konflik.

\section{METODE PENELITIAN}

Penelitian menggunakan pendekatan kualitatif, dengan cara mengumpulkan data/ informasi mengenai fenomena konflik di Berlan dan Palmeriam. Secara kualitatif data dan informasi hasil pengumpulan data lapangan akan menggambarkan fenomena-fenomena tersebut beserta analisis saling hubungan antar fenomena dan faktor-faktor relevan terkait (deskriptif analisis). Alat dan teknik pengumpulan data yang digunakan adalah studi literatur dan studi lapangan. Studi literatur digunakan untuk mengumpulkan dan menganalisis data yang diperoleh berupa tulisan-tulisan, karya ilmiah dan literatur terkait. Sedangkan studi lapangan dilakukan dengan cara wawancara terhadap informan yang memiliki pengetahuan terkait obyek penelitian. Adapun informan penelitian ini yaitu: tokoh masyarakat (Ketua RW dan Ketua FKDM Kebon Manggis dan Matraman), pemerintah daerah (Lurah Kebon Manggis dan Lurah Palmeriam, Kepala Seksi Pemerintahan dan Kamtib Kelurahan Kebon Manggis dan Kelurahan Palmeriam, dan Kepala 
Sub Bidang Kewaspadaan Kantor Kesbangpol Jakarta Timur, serta Kepala Kepolisian Sektor Matraman.

\section{TINJAUAN PUSTAKA}

\section{A. Definisi Konflik}

Secara etimologi konflik berasal dari bahasa latin Secara etimologi konflik berasal dari bahasa latin configure yang berarti saling berbenturan, menurut Kartini Kartono istilah ini termasuk semua bentuk benturan, tabrakan, ketidakserasian, pertentangan, perkelahian, oposisi dan interaksiinteraksi yang antagonis-bertentangan(Kartono, 1990: 173). Sedangkan secara sosiologis konflik diartikan sebagai suatu proses sosial antara dua orang atau lebih (bisa juga kelompok) dimana salah satu pihak berusaha menyingkirkan pihak lain dengan menghancurkannya atau membuatnya tidak berdaya (diunduh dari http: //id.wikipedia. org/wiki/Konflik). Dalam Kamus Besar Bahasa Indonesia, konflik berarti pertentangan atau percekcokan dan pertentangan sendiri bisa muncul ke dalam bentuk pertentangan ide maupun fisik antara dua belah pihak yang bersebrangan.

Clinton F Fing dalam Kartini Kartono mendefinisikan konflik sebagai berikut:

a) Konflik adalah relasi-relasi psikologis yang antagonistis berkaitan dengan tujuan-tujuan yang tidak bisa dipertemukan, sikap-sikap emosional yang bermusuhan dan strukturstuktur nilai yang berbeda;

b) Konflik adalah interaksi yang antagonis mencakup tingkah laku lahiriah yang tampak jelas mulai dari bentuk-bentuk perlawanan halus, terkontrol, tersembunyi sampai pada bentuk perlawanan terbuka, kekerasan perjuangan tidak terkontrol, benturan laten, pemogokan, huru-hara, makar, gerilya perang dan lain-lain (Kartini Kartono. Loc.cit).

Menurut Eep Saefullah Fattah, konflik adalah bentuk perbedaan atau pertentangan ide, pendapat, paham atau kepentingan diantara dua belah pihak atau lebih. Pertentangan ini dapat berbentuk non fisik, bisa juga berkembang menjadi benturan fisik bisa berkadar tinggi dalam bentuk kekerasan (violent) ataupun berkadar rendah yang tidak menggunakan kekerasan (non-violent (Eep Saefullah Fattah, Jurnal Ilmiyah Ulumul Qural No 5 dan 6).Menurut Abu Ahmadi, konflik adalah usaha yang sengaja untuk menentang, melawan atau memaksakan kehendak orang lain. Biasanya konflik itu timbul dari adanya kepentingan yang bertentangan, terutama kepentingan ekonomis, dan sering juga karena perebutan kedudukan dan kekuasaan (Ahmadi, 1975: 93).

Kesenjangan ekonomi kadang juga berpotensi menimbulkan konflik, oleh karena itu kemiskinan juga harus menjadi prioritas untuk dicarikan jalan pemecahannya. Kemiskinan merupakan permasalahan bangsa yang mendesak dan memerlukan langkah-langkah penanganan dan pendekatan yang sistematik (Badan Penelitian dan Pengembangan HAM, 2011: 27).

Sedangkan menurut Simon Fisher, konflik adalah hubungan antara dua pihak atau lebih (individu atau kelompok) yang memiliki, atau yang merasa memiliki, sasaran-sasaran yang tidak sejalan (Fisher, 2001: 8). Menurut Undang-Undang Nomor 7 Tahun 2012 Tentang Penanganan Konflik Sosial, di dalam Pasal 1 ayat (1) konflik didefinisikan sebagai perseteruan dan/ atau benturan fisik dengan kekerasan antara dua kelompok masyarakat atau lebih yang berlangsung dalam waktu tertentu dan berdampak luas yang mengakibatkan ketidakamanan dan disintegrasi sosial sehingga mengganggu stabilitas nasional dan menghambat pembangunan nasional.

Hubungan kekuasaan yang tidak seimbang juga akan berpotensi menimbulkan konflik dalam kehidupan bermasyarakat. Sebagaimana layaknya sebuah konflik, demi eksistensi sistem, sistem akan menciptakan mekanisme untuk meredam konflik tersebut sehingga tidak destruktif terhadap sistem (Badan Penelitian dan Pengembangan HAM, 2011: 101).

Dari berbagai definisi konflik yang dikemukakan di atas, dapat disimpulkan bahwa konflik adalah suatu pertentangan, percekcokan, pertikaan dan perbedaan pendapat antara dua orang atau kelompok yang terjadi karena adanya interaksi sosial, sehingga mengakibatkan pihak yang satu berusaha menyingkirkan pihak yang lain.

\section{B. Penyebab Konflik}

Menurut Maurice Duverger, penyebab terjadinya konflik adalah (1) sebab-sebab individual. Sebab-sebab individual seperti kecenderungan berkompetisi atau selalu tidak selalu puas terhadap pekerjaan orang lain dapat menyebabkan orang yang mempunyai ciri-ciri 


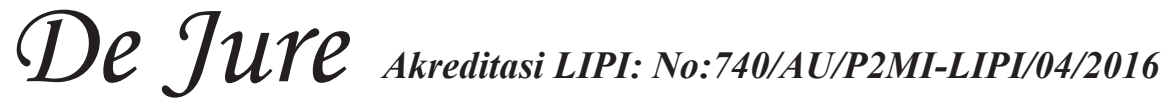

seperti ini selalu terlibat dalam konflik dengan orang lain dimanapun berada, (2) sebab-sebab kolektif, adalah penyebab konflik yang terbentuk oleh kelompok sebagai hasil dari interaksi sosial antara anggota-anggota kelompok. Penyebab konflik ini dihasilkan oleh adanya tantangan dan masalah yang berasal dari luar yang dianggap mengancam kelompoknya (Rauf, 2001: 49-50).

Menurut Simon Fisher penyebab konflik dapat terjadi karena: (Simon Fisher. Log.Cit: 8).

1. Teori hubungan masyarakat. Dalam teori hubungan masyarakat ini menganggap bahwa konflik disebabkan oleh polarisasi yang terus terjadi ketidakpercayaan dan permusuhan diantara kelompok yang berbeda dalam suatu masyarakat. Sasaran yang ingin dicapai teori ini adalah meningkatkan komunikasi dan saling pengertian antara kelompok-kelompok yang mengalami konflik dan mengusahakan toleransi dan agar masyarakat lebih bisa saling menerima keragaman yang ada di dalamnya.

2. Teori negosiasi prinsip. Dalam teori ini menganggap bahwa konflik disebabkan oleh posisi-posisi yang tidak selaras dan perbedaan pandangan tentang konflik oleh pihak-pihak yang mengalami konflik. Sasaran yang ingin dicapai teori ini adalah pertama, membantu pihak-pihak yang mengalami konflik untuk memisahkanperasaanpribadidenganberbagai masalah dan isu, dan memampukan mereka untuk melakukan negosiasi berdasarkan kepentingan-kepentingan mereka daripada posisi tertentu yang sudah tetap dan kedua, melancarkan proses pencapaian kesepakatan yang menguntungkan kedua belah pihak atau semua pihak.

3. Teori kebutuhan manusia. Teori ini berasumsi bahwa konflik yang berakar disebabkan oleh kebutuhan dasar manusia-fisik, mental dan sosial yang tidak terpenuhi atau dihalangi. Keamanan identitas pengakuan partisipasi dan otonomi sering merupakan inti pembicaraan. Sasaran yang ingin dicapai teori ini adalah, pertama, membantu pihak-pihak yang mengalami konflik untuk mengidentifikasi dan mengupayakan bersama kebutuhan mereka yang tidak terpenuhi dan menghasilkan pilihan-pilihan untuk memenuhi kebutuhan-kebutuhan itu dan kedua, agar pihak-pihak yang mengalami konflik mencapai kesepakatan untuk memenuhi kebutuhan dasar semua pihak.

4. Teori Identitas. Teori ini berasumsi bahwa konflik disebabkan karena identitas yang terancam yang sering berakar pada hilangnya sesuatu atau penderitaan dimasa lalu yang tidak diselesaikan. Sasaran yang ingin dicapai teori ini adalah, pertama, melalui fasilitas lokakarya dan dialog antara pihak-pihak yang mengalami konflik mereka diharapkan dapat mengidentifikasi ancaman-ancaman dan ketakutan yang mereka rasakan masingmasing dan untuk membangun empati dan rekonsiliasi diantara mereka dan kedua, meraih kesepakatan bersama yang mengakui kebutuhan identitas semua pihak.

5. Teori kesalahpahaman antar budaya. Teori ini berasumsi bahwa konflik disebabkan oleh ketidakcocokan dalam cara-cara komunikasi diantara berbagai budaya yang berbeda. Sasaran yang ingin dicapai teori ini adalah menambah pengetahuan pihakpihak yang mengalami konflik mengenai budaya pihak lain, mengurangi stereotif negatif yang mereka miliki tentang pihak lain; meningkatkan keefektifan komunikasi antarbudaya.

6. TeoriTransformasikonflik. Teoriiniberasumsi konflik disebabkan oleh masalah-masalah ketidaksetaran dan ketidakadilan yang muncul sebagai masalah sosial, budaya dan ekonomi. Sasaran yang ingin dicapai teori ini adalah, pertama, mengubah berbagai struktur dan kerangka kerja yang menyebabkan ketidaksetaraan dan ketidakadilan termasuk kesenjangan ekonomi, kedua, meningkatkan jalinan hubungan dan sikap jangka panjang diantar pihak-pihak yang mengalami konflik dan ketiga, mengembangkan berbagai proses dan sistem untuk mempromosikan pemberdayaan, keadilan, perdamaian, pengampunan, rekonsiliasi dan pengakuan.

Sedangkan menurut Soerjono Soekanto, ada beberapa hal yang menjadi penyebab konflik yaitu:

1) Perbedaan antara perorangan. Perbedaan pendirian dan perasaan mungkin menyebabkan bentrokan orang-perorangan.

2) Perbedaan kebudayaan. Perbedaan kepribadian dari orang perorangan tergantung puladaripola-polaperkembangankebudayaan 
yang menjadi latar belakang pembentukan serta perkembangan kepribadian tersebut. Seseorang sedikit banyak akan terpengaruh oleh pola-pola pendirian dari kelompoknya. Selanjutnya keadaan tersebut pula menyebabkan terjadinya pertentangan antar kelompok manusia.

3. Bentrokan antar kepentingan-kepentingan bentrokan-bentrokan kepentinganorangperorangan maupun kelompok-kelompok manusia.

4. Perubahan-perubahan sosial. Perubahan sosial yang cepat dalam masyarakat, untuk sementara waktu merubah nilainilai dalam masyarakat dan menyebabkan terjadinya golongan-golongan yang berbeda pendiriannya mengenai reorganisasi sistem nilai-nilai sebagai akibat perubahanperubahan sosial menyebabkan suatu disorganisasi dalam masyarakat.

\section{Penyelesaian Konflik}

Negara berkewajiban menjamin hak dan kebebasan warga negaranya, hal ini telah diamanatkan dalam konstitusi, sebaliknya setiap warga negara juga wajib memenuhi tanggung jawabnya untuk menghormati dan mematuhi segala hal yang berkaitan dengan kewenangan konstitusional. Artinya antara dimensi hak dan kewajiban warga negara dan negara itu saling bertimbal balik (Badan Penelitian dan Pengembangan Hukum dan HAM, 2015: 22).

Pada Undang-Undang Nomor 7 Tahun 2012 tentang Penanganan Konflik Sosial pada Pada Pasal 8 menyebutkan bahwa: (1) penyelesaian perselisihan dalam masyarakat dilakukan secara damai; (2) penyelesaian secara damai sebagaimana dimaksudpadaayat(1)mengutamakanmusyawarah untuk mufakat; dan (3) hasil musyawarahmufakat sebagaimana dimaksud pada ayat (2) mengikat para pihak. Dalam menyelesaikan konflik antara warga Berlan dengan Palmeriam, Pemerintah Daerah melakukan pertemuan yang dihadiri oleh Muspika Kecamatan Matraman dan para tokoh masyarakat dari Berlan maupun Matraman. Pertemuan tersebut membahas mengenai perdamaian antara kedua belah pihak, diharapkan dengan pertemuan tersebut dapat tidak ada lagi konflik antara Berlan dengan Palmeriam. Upaya penyelesaian konflik melalui pertemuan untuk perdamaian ini, merupakan implementasi Pasal 8 Undang-Undang Nomor 7 Tahun 2012.

Dengan diterbitkannya Undang-Undang Nomor 7 Tahun 2012, Pemerintah telah mempunyai regulasi yang dapat dijadikan acuan dalam penyelesaian konflik sosial. Tujuan dari Undang-Undang ini adalah agar tercipta suasana yang aman, tenteram, tertib, damai, dan sejahtera baik lahir maupun batin sebagai wujud hak setiap orang atas perlindungan agama, diri pribadi, keluarga, kehormatan, martabat, dan harta benda.

\section{HASIL PENELITIAN}

Berlan merupakan sebuah komplek perumahan yang berada di Kelurahan Kebon Manggis, Kecamatan Matraman, Jakarta Timur. Kebon Manggis memiliki empat RW, dan Berlan masuk dalam wilayah RW III. Warga Berlan sebagian besar adalah anggota TNI AD baik yang masih aktif maupun yang sudah purna. Di Berlan juga terdapat sekolah SMP dan SMA yang memungkinkan orang dari luar untuk masuk ke lingkungan Berlan. Sementara di seberang jalan dari komplek Berlan adalah Kelurahan Palmeriam, yang hanya dipisahkan oleh Jalan Matraman Raya. Palmeriam merupakan salah satu Kelurahan di Kecamatan Matraman, Jakarta Timur, dan Palmeriam terdiri dari 12 (dua belas) RW. Secara administrasi Berlan dengan Palmeriam samasama berada di wilayah Kecamatan Matraman. Bagi warga Jakarta, Jalan Matraman Raya tentu tidak asing lagi karena wilayah ini amat terkenal dengan perkelahian antar warga, kejadian tersebut jelas-jelas mengganggu dan bahkan merugikan kehidupan warga Jakarta pada umumnya.

Berdasarkan temuan lapangan didapatkan beberapa hal yang menjadi penyebab konflik antara warga Berlan dengan Palmeriam, diantaranya: (1) rebutan lahan parkir, dan rebutan menjadi "polisi cepek" (pak ogah), karena dahulu ada putaran balik di jalan matraman raya, yang pertama di depan restoran minang roda dan yang kedua di depan Hotel Mega Matra; (2) pada awalnya merupakan kenakalan remaja biasa, namun kemudian konflik antara warga Berlan dengan Palmeriam ini merembet menjadi permasalahan yang memiliki nuansa politik, warga Berlan yang mayoritas "anak kolong" (putra-putri anggota ABRI) merupakan simpatisan Golongan Karya (Golkar), sedangkan warga Palmeriam merupakan simpatisan Partai 


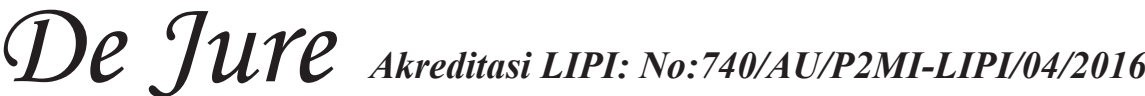

Persatuan Pembangunan (PPP) terlibat bentrok di saat mereka sedang melakukan kampanye; (3) dahulu pernah ada seorang pengusaha besar yang mengincar daerah Berlan dengan Palmeriam (tepatnya di jalan Matraman Raya) karena daerah ini dipandang sangat strategis. Pengusaha tersebut berusaha agar warga yang tinggal di daerah tersebut menjadi tidak nyaman agar mereka mau melepas tanah dan bangunannya dengan harga murah; (4) adanya pihak luar yang tidak bertanggungjawab yang sengaja memanfaatkan situasi ini, agar muncul stigma negatif terhadap warga Berlan dengan Palmeriam yang dikenal sering berkonflik (Wawancara dengan Kepala Seksi Pemerintahan Kelurahan Kebon Manggis dan Ketua FKDM Kelurahan Kebon Manggis).

Pada kesempatan lain, Lurah Palmeriam menjelaskan penyebab konflik pada saat malam takbiran (17 Juli 2015), tawuran ini hanya bersumber dari masalah kecil yaitu dari sekelompok remaja yang melakukan takbir keliling, saling ledek, dan menyalakan petasan. Salah satu kelompok mengejek kelompok lain yang konvoi. Tindakan meledek berujung pada tawuran. Sebenarnya sekelompok remaja yang melakukan takbir keliling tadi adalah orang dari luar Berlan maupun Palmeriam, tetapi karena terjadi kesalahpahaman akhirnya mengakibatkan konflik antara warga Berlan dengan Palmeriam. Hal senada juga dikemukakan oleh Ketua FKDM Palmeriam, bahwa tawuran pada tanggal 17 Juli 2015 terjadi pada pukul 03.30 WIB, disaat para tokoh dan warga selesai melakukan ronda. Mulanya pada pukul 00.00 Wib di jalan tegalan (depan restoran sederhana) antara anak remaja RW III palmeriam bergabung dengan anak remaja kayu manis melawan orang luar (orang lewat). Kemudian tawuran tersebut berkembang menjadi tawuran antara warga Berlan dengan Palmeriam.

Menurut Kepala Kepolisian Sektor Matraman, konflik Berlan dan Palmeriam dinyatakan sudah tidak ada, karena kedua belah pihak sudah menyadari dan mereka ingin hidup berdampingan secara damai. Terkait tawuran pada saat malam takbiran itu bukan warga palmeriam maupun berlan, itu adalah masyarakat umum, yang kebetulan lewat di jalan matraman raya. Kemudian ada warga yang menyalakan petasan yang mengenai asrama TNI, kemudian TNI mengejar yang menyalakan petasan, dan itu juga menyebabkan warga berlan marah, kemudian terjadi lempar-lemparan antara kedua belah pihak (Wawancara dengan Kepala Kepolisian Sektor Matraman).

Konflik antara warga Berlan dengan Palmeriam juga menimbulkan dampak negatif,warga sekitar merasa dirugikan dengan adanya tawuran tersebut, yang lebih dikhawatirkan lagi terjadinya salah sasaran, karena banyak anakanak remaja yang ada di sekitar daerah tersebut. Kalau yang sampai menimbulkan kerusakan rumah terjadi pada dahulu kala, sebelum pinggiran jalan matraman raya dibangun kantor-kantor TNI $\mathrm{AD}$, dulu terjadi pembakaran dan pengrusakanpengrusakan warung atau took-toko di sepanjang jalan matraman raya. Selain itu juga stigma masyarakat terhadap Berlan dan Palmeriam yang terkenal dengan tawurannya. Pada saat tawuran terjadi kadang warga terkena bacok yang diakibatkan salah sasaran, kekhawatiran warga pada saat terjadi tawuran, bahkan pada tahun 1997 terjadi konflik yang berskala besar besar yang sampai menimbulkan banyak korban dan toko-toko pada tutup. Kaitannya dengan hak asasi manusiaadalah terganggunya hak setiap orang atas rasa aman dan tenteram, serta hak atas perlindungan terhadap ancaman ketakutan untuk berbuat atau tidak berbuat sesuatu, yang akan dijelaskan lebih lanjut di bagian Analisis.

Aktor dalam konflik antara warga Berlan dengan Palmeriam adalah anak-anak remaja tanggung yang rata-rata masih duduk di bangku Sekolah Menengah Pertama (SMP) dan Sekolah Menengah Atas (SMA) maupun pengangguran (Wawancara dengan Ketua FKDM Kebon Manggis). Anak-anak seusia ini memang sangat mudah terprovokasi dan belum mampu mengendalikan emosional. Mengingat di Berlan juga terdapat beberapa sekolah negeri maupun swasta maka tidak menutup kemungkinan orang luar dari Berlan dan Palmeriam juga masuk dan berinteraksi di lingkungan situ. Hal inilah yang menjadi faktor bahwa aktor tawuran tidak hanya warga Berlan dengan Palmeriam saja, tetapi juga orang luar yang melakukan aktifitasnya di lingkungan Berlan maupun Palmeriam. Menurut keterangan dari para informan, tidak ada regenerasi aktor dalam konflik antara warga Berlan dengan Palmeriam. Karena konflik yang terjadi sekarang ini hanya secara tiba-tiba saja, tidak direncanakan terlebih dahulu. 
Upaya penyelesaian yang telah dilakukan oleh Pemerintah, atau tokoh masyarakat dalam menyelesaikan tawuran antar warga Berlan dengan Palmeriam, diantaranya:(1)pihak Pemda membangun pagar pembatas yang ada di tengahtengah jalan Matraman Raya, hal ini bertujuan untuk mempersulit orang yang mau nyeberang ke Berlan maupun Palmeriam; (2) membentuk Forum Komunikasi Persaudaraan Masyarakat Matraman (FKPMM) dan membangun Posko Bersama. Pembentukan FKPMM adalah salah satu langkah yang tepat dalam menanggulangi konflik antar warga Berlan dengan Palmeriam, dan pelibatan tokoh pemuda pada setiap pertemuan dalam wadah tersebut diharapkan dapat menyelesaikan setiap permasalahan khususnya menyangkut konflik antar warga tersebut.

Selain FKPMM, pemerintah daerah juga membentukForumKomunikasi KewaspadaanDini Masyarakat (FKDM). FKDM dibentuk melibatkan berbagai unsur yang terdiri dari ormas, perguruan tinggi, tokoh masyarakat, tokoh adat, tokoh agama, tokoh pemuda dan elemen masyarakat lainnya. Di tingkat provinsi penyelenggara FKDM menjadi tanggungjawab dan dilaksanakan oleh masyarakat yang difasilitasi dan dibina oleh pemerintah provinsi. Begitu juga di tingkat kabupaten/kota difasilitasi dan dibina oleh pemerintah kabupaten dan kota, bahkan sampai tingkat kecamatan dan desa sesuai dengan tingkatannya dibina oleh pemerintah kecamatan dan desa pula.

FKDM merupakan amanat dari Peraturan Menteri Dalam Negeri Nomor 12 Tahun 2006, yang mempunyai tugas menjaring, menampung, mengkoordinasikan dan mengkomonikasikan data dan informasi dari masyarakat mengenai potensi ancaman keamanan. Termasuk juga gejala atau peristiwa bencana alam dalam rangka upaya pencegahan dan penanggulangannya secara dini. Selain itu, FKDM juga mempunyai tugas memberikan rekomendasi sebagai bahan pertimbangan bagi Gubernur (untuk tingkat provinsi), Walikota/Bupati (untuk tingkat Kota/ Kabupaten), Camat (untuk tingkat Kecamatan), Lurah/Kepala Desa (untuk tingkat Kelurahan/ Desa). FKDM ini di bentuk sebagai salah satu instrumen dalam memelihara kerukunan nasional. Ini sangat dibutuhkan negara seperti Indonesia untuk mencegah terjadinya upaya dis-orientasi bangsa.
Selain beberapa hal tersebut, pemerintah daerah juga melakukan perdamaian dengan mempertemukan dua belah pihak yang dihadiri para tokoh masyarakat, agar tidak terjadi lagi konflik di Berlan dan Palmeriam. Untuk orang tua dihimbau agar melakukan pembinaan kepada anak-anaknya. Pemerintah daerah membangun pagar pembatas yang berada di tengah Jalan Matraman Raya, ini bertujuan untuk mempersulit warga dalam melakukan serangan, baik ke Berlan maupun ke Palmeriam. Di samping itu, pemerintah daerah juga membantu dalam menyediakan sarana prasarana olah raga, agar para remaja dapat mengisi waktu luangnya dengan hal-hal positif (olah raga). Dan salah satu faktor tidak terjadinya konflik lagi antara warga Berlan dengan Palmeriam adalah ada warga Berlan yang dulu merupakan tokoh pemuda, sekarang tinggal dan menjabat sebagai salah satu ketua RW di Palmeriam.

Terkait dengan konflik yang terjadi pada saat malam takbiran (tanggal 17 Juli 2015) di Jalan Matraman Raya, Muspika Matraman sudah melakukan pertemuan di Rumah Makan Sederhana, pertemuan tersebut bertujuan agar tidak terjadi konflik lagi antara Berlan dengan Palmeriam. Salah satu kesepakatan hasil pertemuan tersebut adalah pemasangan spanduk di tempat-tempat strategis di Berlan dan Palmeriam yang bertuliskan "Kami Damai".

\section{ANALISIS}

\section{A. Faktor penyebab konflik antara warga Berlan dengan Palmeriam}

Menurut Eep Saefullah Fattah, konflik adalah bentuk perbedaan atau pertentangan ide, pendapat, paham atau kepentingan diantara dua belah pihak atau lebih. Pertentangan ini dapat berbentuk non fisik, bisa juga berkembang menjadi benturan fisik bisa berkadar tinggi dalam bentuk kekerasan (violent) ataupun berkadar rendah yang tidak menggunakan kekerasan (non-violent). Sedangkan pada Pasal 5 butir a Undang-Undang Nomor 7 Tahun 2012 tentang Penanganan Konflik Sosial, disebutkan bahwa konflik dapat bersumber dari: permasalahan yang berkaitan dengan politik, ekonomi, dan sosial budaya. Konflik antara Berlan dengan Palmeriam pernah juga dikategorikan pada konflik yang disebabkan oleh perbedaan atau pertentangan politik pada saat masa kampanye, dimana warga Berlan yang mayoritas "anak 


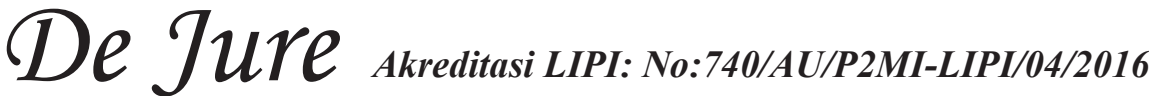

kolong" (putra-putri anggota ABRI) merupakan simpatisan Golongan Karya (Golkar), sedangkan warga Palmeriam merupakan simpatisan Partai Persatuan Pembangunan (PPP). Konflik tersebut juga berujung pada kekerasan atau dapat disebut dengan berkadar tinggi.

Menurut Abu Ahmadi, konflik adalah usaha yang sengaja untuk menentang, melawan atau memaksakan kehendak orang lain. Biasanya konflik itu timbul dari adanya kepentingan yang bertentangan, terutama kepentingan ekonomis, dan sering juga karena perebutan kedudukan dan kekuasaan. Hal ini juga dibuktikan dengan temuan lapangan yang menyatakan bahwa konflik antara Berlan dengan Palmeriam juga disebabkan karena rebutan lahan parkir, dan rebutan menjadi "polisi cepek"(pakogah). Mereka sama-sama mempunyai kepentingan ekonomi, yaitu guna mencari nafkah untuk memenuhi kebutuhan sehari-hari. Gesekan kepentingan ekonomi inilah yang kemudian menimbulkan konflik antara kedua belah pihak.

Soerjono Soekanto, mengemukakan bahwasalahsatupenyebabkonflikadalah bentrokan antar kepentingan-kepentingan, bentrokan kepentinganorang-perorangan maupun kelompokkelompok manusia. Konflik antara Berlan dengan Palmeriam juga melibatkan kelompok-kelompok warga yang notabene masih berusia remaja. Karena menurut Soesilowindradini, usia remaja sangat berkaitan dengan masa emosional, dimana emosi yang dialami oleh anak-anak remaja antara lain: marah, takut, cemas rasa ingin tahu, iri hati, sedih, kasih sayang, dan beberapa emosi lainnya.

Menurut Simon Fisher konflik dapat terjadi karena kesalahpahaman antar budaya. Teori ini berasumsi bahwa konflik disebabkan oleh ketidakcocokan dalam cara-cara komunikasi diantara berbagai budaya yang berbeda. Meskipun salah satu penyebab konflik antara warga Berlan dengan Palmeriam ini bukan karena kesalahpahaman antar budaya, tapi disebabkan karena kesalahpahaman penafsiran. Kesalahpahaman penafsiran yang dimaksud adalah pada saat terjadinya konflik di malam takbiran tanggal 17 Juli 2015, sebenarnya yang menjadi penyebab konflik pada saat itu adalah adanya sekelompok remaja yang melakukan takbir keliling yang berasal dari luar Berlan maupun Palmeriam, tetapi karena terjadi kesalahpahaman akhirnya mengakibatkan konflik antara warga Berlan dengan Palmeriam.

\section{B. Dampak yang diakibatkan dari konflik antara warga Berlan dengan Palmeriam}

Sebagaimana yang telah dideskripsikan pada bagian sebelumnya, konflik antara warga Berlan dengan Palmeriam juga menimbulkan dampak negatif,warga sekitar merasa dirugikan dengan adanya tawuran tersebut, yang lebih dikhawatirkan lagi terjadinya salah sasaran, karena banyak anakanak remaja yang ada di sekitar daerah tersebut. Kalau yang sampai menimbulkan kerusakan rumah terjadi pada dahulu kala, sebelum pinggiran jalan matraman raya dibangun kantor-kantor TNI $\mathrm{AD}$, dulu terjadi pembakaran dan pengrusakanpengrusakan warung atau took-toko di sepanjang jalan matraman raya. Selain itu juga stigma masyarakat terhadap Berlan dan Palmeriam yang terkenal dengan tawurannya. Pada saat tawuran terjadi kadang warga terkena bacok yang diakibatkan salah sasaran, kekhawatiran warga pada saat terjadi tawuran, bahkan pada tahun 1997 terjadi konflik yang berskala besar besar yang sampai menimbulkan banyak korban dan toko-toko pada tutup. Kaitannya dengan hak asasi manusiaadalah terganggunya hak setiap orang atas rasa aman dan tenteram, serta hak atas perlindungan terhadap ancaman ketakutan untuk berbuat atau tidak berbuat sesuatu, sebagaimana telah dijelaskan pada Pasal 30 Undang-Undang Nomor 39 tentang Hak Asasi Manusia. Kemudian ditegaskan lagi pada Pasal 35 yaitu setiap orang berhak hidup di dalam tatanan masyarakat dan kenegaraan yang damai, aman, dan tenteram, yang menghormati, melindungi, dan melaksanakan sepenuhnya hak asasi manusia dan kewajiban dasar manusia sebagaimana diatur dalam Undangundang ini.

Secara konstitusional, Pasal 28G ayat (1) Undang-Undang Dasar Negara Republik Indonesia Tahun 1945 menyebutkan bahwa setiap orang berhak atas perlindungan diri pribadi, keluarga, kehormatan, martabat dan harta benda yang dibawah kekuasaannya, serta berhak atas rasa aman dan perlindungan dari ancaman ketakutan untuk berbuat atau tidak berbuat sesuatu yang merupakan hak asasi. Oleh sebab itu Pemerintah berkewajiban untuk melakukan intervensi dalam penanganan konflik, agar setiap warga negara dapat memperoleh hak atas rasa aman. 


\section{Upaya penyelesaian yang telah dilakukan oleh Pemerintah Kota dalam menyelesaikan konflik antar warga Berlan dengan Palmeriam sesuai dengan amanat Undang-Undang Nomor 7 Tahun 2012}

Salah satu upaya Pemerintah untuk mengatasi konfliksosial adalahdenganmengeluarkanUndangUndang Nomor 7 Tahun 2012 tentang Penanganan Konflik Sosial, karena disadari bahwa konflik sosial terbukti telah mengakibatkan hilangnya rasa aman, timbulnya rasa takut masyarakat, kerugian harta benda, korban jiwa dan trauma psikologis seperti dendam, benci dan antipati. Kemudian sebagai upaya dalam menyelesaikan konflik antara warga Berlan dengan Palmeriam, pihak Pemerintah Kota telah melakukan berbagai upaya, sebagaimana Pada Pasal 8 menyebutkan bahwa: (1) penyelesaian perselisihan dalam masyarakat dilakukan secara damai; (2) penyelesaian secara damai sebagaimana dimaksud pada ayat (1) mengutamakan musyawarah untuk mufakat; dan (3) hasil musyawarahmufakat sebagaimana dimaksud pada ayat (2) mengikat para pihak. Dalam menyelesaikan konflik antara warga Berlan dengan Palmeriam, Pemerintah Daerah melakukan pertemuan yang dihadiri oleh Muspika Kecamatan Matraman dan para tokoh masyarakat dari Berlan maupun Matraman. Pertemuan tersebut membahas mengenai perdamaian antara kedua belah pihak, diharapkan dengan pertemuan tersebut dapat tidak ada lagi konflik antara Berlan dengan Palmeriam. Upaya penyelesaian konflik melalui pertemuan untuk perdamaian ini merupakan implementasi Pasal 8 Undang-Undang Nomor 7 Tahun 2012.

Selain itu, dalam rangka meredam potensi konflik, pemerintah daerah juga telah melakukan perencanaan dan pelaksanaan pembangunan dengan memperhatikan aspirasi masyarakat. Hal ini dibuktikan dengan disediakannya sarana prasarana olah raga, agar para remaja dapat mengisi waktu luangnya dengan hal-hal positif (olah raga), meskipun sarana dan prasarana tersebut masih dirasa kurang oleh masyarakat. Hal ini merupakan implementasi Pasal 9 huruf a Undang-Undang Nomor 7 Tahun 2012. Selain itu, dalam rangka meredam konflik Pemerintah Kota juga menyelenggarakan kegiatan outbound. Kegiatan ini melibatkan kedua belah pihak, baik warga Berlan maupun Palmeriam. Dengan kegiatan ini diharapkan terjalin rasa persaudaraan, saling kenal, saling silaturahmi, saling percaya dan tidak melihat kawan atau lawan diantara mereka yang pada akhirnya memunculkan rasa solidaritas bersama. Hingga mereka dapat membawa misi untuk menjaga wilayahnya agar tidak terjadi perkelahian kembali.

Lebih lanjut pada Pasal 52 menjelaskan bahwa masyarakat dapat berperan serta dalam Penanganan Konflik. Jika dikaitkan dengan peran serta warga masyarakat dalam penyelesaian konflik antara warga Berlan dengan Palmeriam adalah bahwasanya warga, maupun tokoh masyarakat selalu bersifat kooperatif dalam mendukung kebijakan Pemerintah, hal ini dibuktikan dengan temuan lapangan bahwa warga ataupun tokoh masyarakat selalu hadir dalam pertemuan yang membahas tentang penyelesaian konflik antar warga tersebut.

Selain pihak Pemerintah Kota, Kepolisian Sektor Matraman juga telah melakukan tindakan preventif dalam memberikan pemenuhan kepada warga atas hak rasa aman. Hal ini dibuktikan dengan melakukan pendekatan kepada warga melalui Sistem Komunikasi Masyarakat disingkat Siskomas; Kelompok Sadar Keamanan dan Ketertiban Masyarakat, disingkat Pokdarkamtibmas; patroli sekala sedang (yang salah satunya menghalau anak-anak yang nongkrong sampai larut malam). Selain tindakan preventif, Kepolisian Sektor Matraman juga telah melakukan tindakan represif yaitu dengan melakukan penangkapan pada pelaku tawuran yang tidak mengindahkan peringatan dari aparat kepolisian.

\section{SIMPULAN}

Beberapa hal yang menjadi simpulan dari penelitian Penyelesaian Konflik Sosial Kasus Tawuran Warga Berlan dengan Palmeriam. Hal yang menjadi penyebab konflik antara warga Berlan dengan Palmeriam diantaranya: (a) rebutan lahan parkir, dan rebutan menjadi "polisi cepek" (pak ogah); (b) awalnya hanya kenakalan remaja biasa, namun kemudian konflik antara warga Berlan dengan Palmeriam ini merembet menjadi permasalahan yang memiliki nuansa politik; dan (c) kesalahpahaman, hal ini terjadi karena jalan Matraman Raya merupakan salah satu jalanbesar yang siapapun dapat melewati jalan tersebut. Meskipun ada beberapa faktor yang menyebabkan konflik antara warga Berlan dengan Palmeriam, 


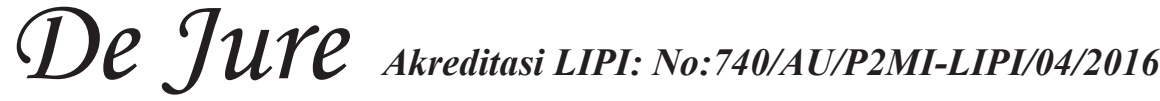

namun kesalahpahaman dan kenakalan remaja merupakan faktor yang dominan penyebab konflik tersebut.

Dampak yang diakibatkan dari konflik antara warga Berlan dengan Palmeriam adalah warga sekitar merasa dirugikan dengan adanya tawuran tersebut, yang lebih dikhawatirkan lagi terjadinya salah sasaran, karena banyak anak-anak remaja yang ada di sekitar daerah tersebut. Kaitannya dengan hak asasi manusiaadalah terganggunya hak setiap orang atas rasa aman dan tenteram, serta hak atas perlindungan terhadap ancaman ketakutan untuk berbuat atau tidak berbuat sesuatu.

Upaya Pemerintah Kota dalam menyelesaikan konflik antara warga Berlan dengan Palmeriam, diantaranya: (a) dilakukan pertemuan yang dihadiri oleh Muspika Kecamatan Matraman dan para tokoh masyarakat dari Berlan maupun Matraman; (b) menyediakan sarana prasarana olah raga, agar para remaja dapat mengisi waktu luangnya dengan hal-hal positif (olah raga), meskipun sarana dan prasarana tersebut masih dirasa kurang oleh masyarakat; dan (c) pemerintah daerah juga menyelenggarakan kegiatan outbound dalam meredam konflik, dengan melibatkan kedua belah pihak, namun kegiatan ini sekarang sudah tidak ada lagi.Dari upaya yang telah dilakukan pemerintah kota tersebut, peneliti mempunyai pandangan tersendiri terkait upaya yang peneliti pandang efektif dalam menyelesaikan konflik, dan upaya yang dimaksud akan dituangkan dalam rekomendasi di bawah ini.

\section{SARAN}

Kepada Pemerintah KotaAdministrasi Jakarta Timur agar mengalokasikan anggaran untuk menambah sarana prasarana olah raga di wilayah Berlan maupun Palmeriam, menghidupkankembali kegiatan outbond yang melibatkan para remaja warga Berlan maupun Palmeriam, membangun Posko bersama di Palmeriam yang lokasinya di salah satu titik disepanjang Jalan Matraman Raya yang merupakan jalan pembatas antara Palmeriam dengan Berlan, menetapkan program yang berkaitan dengan keamanan dan ketertiban sebagai program prioritas di Tahun 2017, dan menambah porsi program bidang perekonomian dengan melakukan pembinaan dan pelatihan kewirausahaan dan pemberian pinjaman modal kepada warga khususnya bagi pengangguran.
Untuk Lurah Kebon Manggis dan Lurah Palmeriam agar melakukan sosialisasi tentang dampak negatif dari konflik antar warga, menyelenggarakan kegiatan sosial, misalnya kerja bakti bersama atau bakti sosial yang melibatkan remaja Berlan maupun Palmeriam. Selain itu, Lurah harus sering turun ke lapangan, bergaul dengan masyarakat dan mendengar aspirasi warganya, hal ini dapat dibantu oleh Ketua maupun anggota FKDM, atau bahkan Kepala Seksi Pemerintahan dan Keamanan dan Ketertiban. Kemudian untuk warga Berlan dengan Palmeriam agar meningkatkan peran serta dalam mendukung kebijakan dari Pemerintah terkait penyelesaian konflik. Hal ini dilakukan dalam rangka menciptakan kondisi damai sehingga hak atas rasa aman masyarakat dapat terpenuhi.

Rekomendasi ketiga penulis tujukan kepada Kepolisian Sektor Matraman agar menambah volume patroli, hal ini dikarenakan beberapa konflik yang terjadi bermula saat penurunan intensitas patroli kepolisian. 


\section{DAFTAR KEPUSTAKAAN}

\section{Buku:}

Ahmadi, Abu, Pengantar Sosiologi, Surakarta: Ramadhani, 1975.

Awani, dkk, Irewati, Kerusuhan Sosial di Indonesia, Jakarta: Grasindo, 2001.

Badan Penelitian dan Pengembangan HAM, Potensi Konflik Kekerasan antar Kelompok Narapidana dalam Lembaga Pemasyarakatan: Jakarta: Badan Penelitian dan Pengembangan HAM, 2011.

Badan Penelitian dan Pengembangan HAM, Penanganan Masyarakat Miskin Kota dalam Perspektif Hukum dan HAM: Jakarta: Badan Penelitian dan Pengembangan HAM, 2011.

Badan Penelitian dan Pengembangan Hukum dan HAM, Anatomi Sengketa Agraria yang Menimbulkan Konflik Sosial: Jakarta: Badan Penelitian dan Pengembangan Hukum dan HAM, 2015.

Fattah E., Saefullah, Manajemen Konflik Politik dan Demokrasi, Jurnal Ilmiyah Ulumul Qural No 5 dan 6.

Fisher, Simon, Mengelola Konflik Keterampilan dan Strategi Untuk Bertindak, British Counsil, Indonesia, Jakarta, 2001.

Kartono, Kartini, Pemimpin dan Kepemimpinan, Jakarta: Rajawali, 1990.

Mushadi, dkk, Mediasi dan Resolusi Konflik di Indonesia (Dari Konflik Agama hingga Mediasi Peradilan), Semarang: Walisongo Mediation Center, 2007.

Rahardjo, Satjipto, Pemanfaatan Ilmu-Ilmu Sosial Bagi Pengembangan Ilmu Hukum, Bandung: Alumni, 1977.

Rauf, Maswadi, Konsensus Politik dan Konflik Politik, Jakarta: Dirjen Dikti Depdiknas, 2001.

Shahab, Alwi, Robinhood Betawi: Kisah Betawi Tempoe Doeloe, Jakarta: Republika, 2001.

Soekanto, Soerjono, Sosiologi Suatu Perubahan, Jakarta: Graha Grafindo, 1995.

Susan, Novri, Sosiologi Konflik dan Isu-Isu Konflik Kontemporer, Jakarta: Kencana, 2009.

\section{Undang-Undang}

Undang-Undang Dasar Negara Republik Indonesia Tahun 1945.

Undang-Undang Nomor 39 tentang Hak Asasi Manusia.

Undang-Undang Nomor 7 Tahun 2012 tentang Penanganan Konflik Sosial.

\section{Internet}

Merdeka.com/jakarta/kapolda-metro-bakalbertemu-ahok-bahas-maraknya-tawuranwarga.html diakses 10 Agustus 2015 pukul $12.45 \mathrm{Wib}$.

Poskotanews.com/2015/07/28/wagub-jakartatimur-terbanyak-kasus-tawuran/ diakses 10 Agustus 2015 pukul 13.24 Wib.

Roeshman.blogspot.com/2008/06/perseteruanbebuyutan-di-kawasan.html? $\mathrm{m}=1$ diakses 10 Agustus 2015 pukul 13.34 Wib.

Detik.com/news/berita/2970679/tawuran-wargapecah-di-berlan-warga-bawa-pedang-danlempar-batu diakses pada 10 Agustus 2015 pukul 13.43 Wib.

http://news.liputan6.com/read/22759/jakartafrustrasi-tawuran-menggelanggang diakses pada 8 Oktober 2015 pukul 10.13 Wib. 


\section{De JuYe akreditasi LIPI: No:740/AU/P2MI-LIPI/04/2016}

\section{BIODATA PENULIS}

Nama, Yuliyanto, S.H., M.H., adalah Peneliti Muda pada Pusat Penelitian dan Pengembangan Hukum, Badan Penelitian dan Pengembangan Hukum dan HAM, Kementerian Hukum dan HAM R.I., lahir di Sragen, tanggal 21 Juni 1980. Gelar Sarjana Hukum diperoleh dari Fakultas Hukum Universitas Muhammadiyah Surakarta pada Tahun 2005, sedangkan gelar Magister Hukum diperoleh dari Universitas Jayabaya Jakarta pada tahun 2013. 


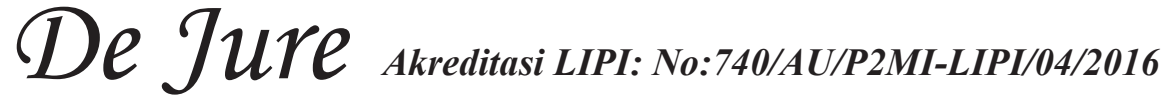

\section{PEDOMAN PENULISAN NASKAH JURNAL PENELITIAN HUKUM DE JURE}

1. Naskah yang dimuat dalam Jurnal Penelitian Hukum De Jure adalah tulisan yang belum pernah dipublikasikan dalam media massa.

2. Naskah yang dimuat dalam Jurnal Penelitian Hukum De Jure meliputi tulisan tentang hasil penelitian (penelitian empiris maupun penelitian normatif atau studi dokumenter), pemikiran dan informasi lain yang bersifat ilmiah.

3. Menggunakan bahasa Indonesia yang baku.

4. Sistimatika Penulisan :

A. Naskah artikel hasil penelitian empiris :

o Judul aktual

Menggambarkan isi naskah dan maksimal 14 kata ditulis dalam bahasa Indonesia dan Inggris

o Nama penulis

Tanpa gelar akademik, jabatan, kepangkatan, alamat lembaga/instansi dan e-mail

o Abstrak

Berisi Latar Belakang, Rumusan Masalah, Tujuan, Kegunaan, Metode, Isi

Pembahasan, Analisis, Kesimpulan dan Saran Temuan ditulis dalam satu spasi;

150 kata (10-20 baris/ satu (1) paragraf) diketik menggunakan huruf Times New

Roman; font 11 italic; ditulis dalam bahasa Indonesia dan bahasa Inggris.

o Kata Kunci

Mengandung yang di indekskan ditulis dalam bahasa Indonesia dan Inggris

dengan minimal 3 kata maksimal 5 kata

- PENDAHULUAN

Berisi latar belakang masalah dan rumusan masalah, tujuan, kegunaan, kerangka Teori/Konsep, Metode (metode penelitian yang digunakan, di antaranya meliputi jenis penelitian, lokasi penelitian, sumber data, teknik pengumpulan data, pengolahan data dan analisis data.)

- PEMBAHASAN

Berisi, pembahasan terhadap masalah yang diteliti

- Analisis

Berisi analisis dari semua pokok pembahasan

- PENUTUP

Kesimpulan dan saran

Kesimpulan dan saran ditulis dalam bentuk uraian bukan dalam bentuk'angka

- DAFTAR KEPUSTAKAAN

Daftar Pustaka : ditulis berdasarkan abjad, dengan urutan : Nama pengarang. Judul buku. Kota penerbit: nama penerbit, tahun penerbitan.

Contoh ....Hamzah. Andi, Bantuan Hukum suatu Tinjauan Yuridis. Ghalia

Indonesia, Jakarta, 1983. 


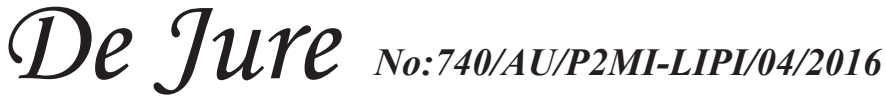

B. Naskah artikel ulasan Hasil penelitian normatif atau studi dokumenter), pemikiran dan informasi lain yang bersifat ilmiah.

o Judul aktual

Menggambarkan isi naskah dan maksimal 14 kata ditulis dalam bahasa

Indonesia dan Inggris

o Nama penulis

Tanpa gelar akademik, jabatan, kepangkatan, alamat lembaga/instansi dan e-mail

o Abstrak

Berisi Latar Belakang, Rumusan Masalah, Tujuan, Kegunaan, Metode, Isi

Pembahasan, Analisis, Kesimpulan dan Saran Temuan ditulis dalam satu spasi;

150 kata (10-30 baris/ satu (1) paragraf) diketik menggunakan huruf Times

New Roman; font 11 italic; ditulis dalam bahasa Indonesia dan bahasa Inggris

o Kata Kunci

Mengandung yang di indekskan ditulis dalam bahasa Indonesia dan Inggris

minimal 3 kata maksimal 5 kata

- PENDAHULUAN

Latar belakang masalah dan rumusan masalah

- PEMBAHASAN

Berisi, pembahasan terhadap masalah yang dikaji

- ANALISIS

Berisi analisis dari semua pokok pembahasan

- PENUTUP

Kesimpulan Dan Saran

Kesimpulan dan saran ditulis dalam bentuk uraian bukan dalam bentuk angka

- DAFTAR KEPUSTAKAAN

Daftar Pustaka : ditulis berdasarkan abjad, dengan urutan : Nama pengarang. Judul buku. Kota penerbit : nama penerbit, tahun penerbitan.

Contoh ....Hamzah. Andi, Bantuan Hukum suatu Tinjauan Yuridis. Ghalia

Indonesia, Jakarta, 1983.

5. Naskah dilengkapi dengan indeks.

6. Naskah diketik rapi 1,5 spasi di atas kertas A4; menggunakan huruf Times New Roman; Font 11; antara 20-30 halaman; diprint out dan disertai soft copy CD.

7. Penulisan kutipan sumber rujukan dengan sistem bodynote, yaitu menulisk ${ }^{\wedge} \mathrm{n}$ nama pengarang (tanpa gelar akademik); tahun penerbitan dan no halaman, yang ditulis dalam kurung; diletakan dibelakang kutipan. Contoh : .(Hamzah, 2007: 15)

8. Isi tulisan di luar tanggungjawab redaksi. Dan redaksi berhak mengedit redaksional tanpa merubah arti.

9. Naskah yang belum memenuhi syarat akan dikonfirmasikan atau dikembalikan untuk diperbaiki.

10. Keterangan lengkap dapat menghubungi redaksi Jurnal Peneltian Hukum De Jure melalui Email: jurnaldejure@yahoo.com 
